\title{
DIVERSITY OF PLANT-PARASITIC NEMATODES ON MEDICINAL PLANTS IN ME LINH STATION FOR BIODIVERSITY, VINH PHUC PROVINCE, VIETNAM
}

\author{
Nguyen Huu Tien ${ }^{1,2,3}$, Nguyen Thi Duyen ${ }^{1,2}$, Le Duc Huy ${ }^{4}$, \\ Nobleza Neriza ${ }^{5}$, Trinh Quang Phap ${ }^{1,2, *}$ \\ ${ }^{1}$ Institute of Ecology and Biological Resources, VAST, Vietnam \\ ${ }^{2}$ Graduate University of Science and Technology, VAST, Vietnam \\ ${ }^{3}$ Nematology Unit, Department of Biology, Ghent University, \\ K.L. Ledeganckstraat 35, 9000 Ghent, Belgium \\ ${ }^{4}$ Faculty of Environmental Sciences, VNU University of Science, Vietnam \\ ${ }^{5}$ College of Agriculture, Mindanao State University, Main Campus, \\ Marawi City, 9700 Lanao del Sur, Philippines
}

Received 28 May 2019, accepted 18 July 2019

\begin{abstract}
Plant-parasitic nematodes are known as one of the most important pests attacking various plants in the world, and investigating the nematode component is very essential for management of this pest and prevent damage to plants in general. Our survey of plant-parasitic nematodes on medicinal plants in Me Linh Station for Biodiversity, a place for conservation of precious plants and animals in Vietnam, identified ten species that belong to nine genera, five families, and two orders of plant-parasitic nematodes parasitizing six medicinal plants. Excoecaria cochinchinensis was parasitized by the highest number of nematode genera (5 genera, including Xiphinema, Discocriconemella, Meloidogyne, Helicotylenchus, and Hemicriconemoides), while Hymenocallis littoralis was associated with the highest number of plant-parasitic nematodes (2060 nematodes/250g soil). The results also showed that Discocriconemella limitanea was found to be a dominant species with the highest number of individuals on 6 medicinal plants, and the genus Helicotylenchus had the highest frequency of appearance (5/6 plants or $83.3 \%$ ). These nematodes caused symptoms such as yellowing leaves, root galls, and root lesions, which directly affect the quality and yield of medicinal plants. Based on the results, this study showed that plant-parasitic nematodes are a potential threat to the cultivation of medicinal plants in Me Linh Station for Biodiversity, and thus, control measures should be applied to ensure sustainable cultivation of medicinal plants in this place.
\end{abstract}

Keywords: Bixa Orellana, Excoecaria cochinchinensis, Hymenocallis littoralis, Morinda officinalis, Polyscias fruticosa, Zingiber zerumbet.

Citation: Nguyen Huu Tien, Nguyen Thi Duyen, Le Duc Huy, Nobleza Neriza, Trinh Quang Phap, 2019. Diversity of plant-parasitic nematodes on medicinal plants in Me Linh station for biodiversity, Vinh Phuc Province, Vietnam. Academia Journal of Biology, 41(3): 19-24. https://doi.org/10.15625/2615-9023/v41n3.13849.

*Corresponding author email: tqphap@ gmail.com

C2019 Vietnam Academy of Science and Technology (VAST) 


\section{INTRODUCTION}

The Me Linh Station for Biodiversity belongs to the Institute of Ecology and Biological Resources, located at the border part of Tam Dao National Park in Vietnam. The main function of this station is to organize basic research on biodiversity, maintaining a living-collection of tropical plants and animals, taking measures for the conservation of gene pool, rehabilitation and development of endangered species of plants and animals in Vietnam, as well as develop ex-situ conservation methods by importing plants from outside. Currently, the Me Linh Station for Biodiversity is building a livingcollection of medicinal plants in a botanical garden with many precious plants such as Morinda officinalis How, Polyscias fruticosa (L.) Harms, Hymenocallis littoralis (Jacq.) Salisb, etc.

For successful cultivation of medicinal plants, pest control must be of primary concern in order to limit their outbreak, especially of plant-parasitic nematodes (PPNs) (Perry \& Moens, 2013). Nematodes are highly diverse, complex, and specialized Metazoa that colonize terrestrial, marine, and freshwater habitats from the tropics to the poles (Hickman et al., 2003; De Ley, 2006; Hallem et al., 2011). Plant-parasitic nematodes are one of the most important pests that are seriously threatening the food security of the world, causing an estimated economic loss of at least $12.3 \%$ (157 billion USD) worldwide (Hassan et al., 2013). A number of studies of plant-parasitic nematodes associated with medicinal plants has been executed, and plant-parasitic nematodes are associated with almost all medicinal plants studied to date (Ngo, 2000; Nguyen \& Nguyen, 2000; Khanzada et al., 2007; Nguyen et al., 2015; Abtahi \& Bakooie, 2017; Eapen \& Pandey, 2018). Remarkably, yield losses caused by plant-parasitic nematodes on medicinal plants were up to $30 \%$ (Eapen \& Pandey, 2018).

Furthermore, monoculture of plants might provide more suitable condition for plantparasitic nematodes and increase nematode transmission possibility which may cause serious disease on host plants. Thus, this study is aimed at investigating diversity of plantparasitic nematodes on medicinal plants at $\mathrm{Me}$ Linh Station for Biodiversity, and determining the most important plant-parasitic nematode group based on symptoms, density, and frequency of plant-parasitic nematodes.

\section{MATERIALS AND METHODS}

Sampling: medicinal plants with symptoms such as stunting, yellow leaves, root-knot, root lesion in Me Linh Station for Biodiversity were chosen for collecting samples. After the removal of the detritus layer, about $1 \mathrm{~kg}$ soil and $5 \mathrm{~g}$ roots around the rhizosphere of medicinal plants were collected from the upper $30 \mathrm{~cm}$ soil layer using a core $5 \times 30 \mathrm{~cm}$ (Nguyen et al., 2019b). The soil and roots were kept in a nylon bag, placed in a cool container, and transported to the Department of Nematology in the Institute of Ecology and Biological Resources.

Extraction: nematodes from soil and root were extracted using modified Baermann tray method (Whitehead \& Hemming, 1965). Swollen nematodes were dissected directly from root tissues under a stereomicroscope using a scalpel and forceps (Hartman \& Sasser, 1985).

Fixation and identification: measurements were made based on permanent slides from heat-killed nematodes with a fixation by TAF and ethanol-glycerin dehydration (Nguyen et al., 2017). For morphological examination, nematodes were observed through a Olympus BX-51 light microscope equipped with a drawing tube and digital camera. To confirm morphological identification, ITS and 28S gene regions of nematodes were amplified and sequenced (Nguyen et al., 2019a); specific primers were used for Meloidogyne spp. (Randig et al., 2002).

Calculating density and frequency: after extraction, the nematode suspension was placed in a counting disk under a microscope to count the number of nematodes for each genus. 
Density $=$ total number of a specific genus in a sample

Frequency $=($ the number of a specific genus / total) $\times 100 \%$

\section{RESULTS}

\section{Species component}

This study determined ten species belong to nine genera, five families, and two orders of plant-parasitic nematodes parasitizing medicinal plants in Me Linh Station for
Biodiversity (table 1). Interestingly, 8 species of plant-parasitic nematodes on medicinal plants, namely Scutellonema brachyurum, Helicotylenchus cavenessi, Criconemella curvata, Hemicriconemoides mangiferae, Discocriconemella limitanea, Paratylenchus sp., Tylenchulus semipenetrans, and Xiphinema brevicolle, were recorded as new records on medicinal plants in Vietnam (Ngo, 2000; Nguyen \& Nguyen, 2000; Nguyen et al., 2015).

Table 1. List of plant-parasitic nematodes parasitizing medicinal plants in Me Linh Station for Biodiversity

\begin{tabular}{|c|c|}
\hline \multirow{2}{*}{\multicolumn{2}{|c|}{ TYLENCHIDA THORNE, 1949}} \\
\hline & \\
\hline & Scutellonema Andrassy, 1958 \\
\hline \multirow[t]{2}{*}{1} & S. brachyurum (Steiner, 1938) Andrássy, 1958 \\
\hline & Helicotylenchus Steiner, 1945 \\
\hline 2 & H. cavenessi Sher, 1966 \\
\hline 3 & H. dihystera (Cobb, 1893) Sher, 1961 \\
\hline \multicolumn{2}{|r|}{ Criconematidae Thorne, 1949} \\
\hline & Criconemella de Grisse \& Loof, 1965 \\
\hline \multirow[t]{2}{*}{4} & C. curvata (Raski, 1952) de Grise \& Loof, 1965 \\
\hline & Hemicriconemoides Chitwood \& Birchfield, 1957 \\
\hline \multirow[t]{2}{*}{5} & H. mangiferae Siddiqi, 1961 \\
\hline & Discocriconemella De Grisse \& Loof, 1965 \\
\hline 6 & D. limitanea (Luc, 1959) De Grisse \& Loof, 1965 \\
\hline \multicolumn{2}{|r|}{ Tylenchulidae Skarbilovich, 1974} \\
\hline & Paratylenchus Micoletzki, 1922 \\
\hline \multirow[t]{2}{*}{7} & Paratylenchus sp. \\
\hline & Tylenchulus Cobb, 1913 \\
\hline 8 & T. semipenetrans Cobb, 1913 \\
\hline \multicolumn{2}{|r|}{ Meloidogynidae Filipjev, 1934} \\
\hline & Meloidogyne Goeldi, 1892 \\
\hline 9 & M. incognita (Kofoid \& White, 1919) Chitwood, 1949 \\
\hline \multicolumn{2}{|r|}{ DORYLAIMIDA PEARSE, 1942} \\
\hline \multicolumn{2}{|r|}{ Longidoridae Thorne, 1935} \\
\hline & Xiphinema Cobb, 1913 \\
\hline 10 & X. brevicolle Lordello \& Da Costa, 1961 \\
\hline
\end{tabular}

On all medicinal plants, Discocriconemella limitanea was the most abundant species and occupied $75.9 \%$ of total, followed by
Paratylenchus sp. (occupied $14.6 \%$ of total) (Fig. 1). 


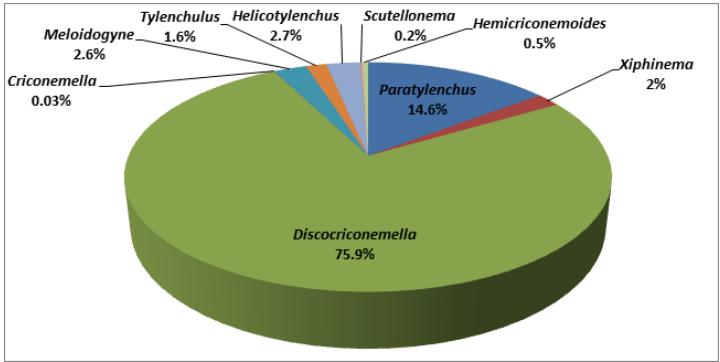

Figure 1. Percentages of the number of plantparasitic nematodes in the rhizosphere of medicinal plants in Me Linh Station for Biodiversity

Density, frequency, and effects of plantparasitic nematodes on medicinal plants in Me Linh Station for Biodiversity

Results of this study showed that plantparasitic nematode composition on each medicinal plant species is different, implying that plant-parasitic nematodes affected differently to each medicinal plant (table 2).

There were three genera of plant-parasitic nematodes parasitizing Polyscias fruticosa (L.) Harms, including Discocriconemella, Helicotylenchus, and Hemicriconemoides. However, densities of plant-parasitic nematodes on Polyscias fruticosa were relatively low, while the density of the genus Helicotylenchus was highest, occupied $88.9 \%$ of the total (24 individuals/250 g soil).

Only two genera, Paratylenchus and Helicotylenchus, were associated with Morinda officinalis, of which the genus Paratylenchus was dominant with 450 individuals $/ 250 \mathrm{~g}$ soil $(91.8 \%$ of total). The relatively high density of plant-parasitic nematodes on this plant shows that plantparasitic nematodes may be a potential threat to yield and quality of Morinda officinalis.

Table 2. Densities of plant-parasitic nematodes in the rhizosphere of medicinal plant in Me Linh Station for Biodiversity

\begin{tabular}{|c|c|c|c|c|c|c|c|}
\hline \multirow[b]{2}{*}{ Genus } & \multicolumn{7}{|c|}{ Plants } \\
\hline & $\begin{array}{l}\text { Polyscias } \\
\text { fruticosa } \\
\text { (L.) Harms }\end{array}$ & $\begin{array}{c}\text { Morinda } \\
\text { officinalis } \\
\text { How }\end{array}$ & $\begin{array}{l}\text { Hymenocallis } \\
\text { littoralis } \\
\text { (Jacq.) }\end{array}$ & $\begin{array}{l}\text { Zingiber } \\
\text { zerumbet } \\
\text { (L.) Sm }\end{array}$ & $\begin{array}{c}\text { Bixa } \\
\text { orellana } \\
\text { L. } \\
\end{array}$ & $\begin{array}{c}\text { Excoecaria } \\
\text { cochinchinensis } \\
\text { Lour. }\end{array}$ & $\begin{array}{c}\text { Frequency } \\
\quad(\%)\end{array}$ \\
\hline Paratylenchus & 0 & 450 & 0 & 0 & 0 & 0 & 16.7 \\
\hline Xiphinema & 0 & 0 & 5 & 0 & 40 & 15 & 50.0 \\
\hline Discocriconemella & 2 & 0 & 2,000 & 0 & 330 & 1 & 66.7 \\
\hline Criconemella & 0 & 0 & 0 & 1 & 0 & 0 & 16.7 \\
\hline Meloidogyne & 0 & 0 & 0 & 50 & 0 & 30 & 33.3 \\
\hline Tylenchulus & 0 & 0 & 50 & 0 & 0 & 0 & 16.7 \\
\hline Helicotylenchus & 24 & 40 & 0 & 6 & 8 & 4 & 83.3 \\
\hline Scutellonema & 0 & 0 & 5 & 0 & 0 & 0 & 16.7 \\
\hline Hemicriconemoides & 1 & 0 & 0 & 0 & 0 & 14 & 33.3 \\
\hline
\end{tabular}

The total number of plant-parasitic nematodes on Hymenocallis littoralis was highest among investigated medicinal plants, and four genera, including Xiphinema, Discocriconemella, Tylenchulus, and Scutellonema, were found in the rhizosphere of this plant, of which the genus Discocriconemella was the most abundant genus with 2,000 individuals/250 g soil and occupied $97.1 \%$ of the total. Densitíes of all other genera were lower than 50 individuals $/ 250 \mathrm{~g}$ soil (2.4\% of total). A high number of Discocriconemella could be the main reason for many lesions on roots of Hymenocallis littoralis.

Three genera of plant-parasitic nematodes were found on Zingiber zerumbet, namely Criconemella, Meloidogyne, and Helicotylenchus, of which density of the genus Meloidogyne was highest, occupied $87.7 \%$ of the total (50 individuals/ $250 \mathrm{~g}$ soil). During this survey, symptoms such as yellowing leaves and root galls were recorded on Zingiber zerumbet, representing the 
pathogenicity of genus Meloidogyne on this plant. Furthermore, Meloidogyne spp. is one of the most damaging pathogens in the world; this nematode group needs to be monitored carefully.

For Bixa orellana, three genera, including Xiphinema, Discocriconemella, and Helicotylenchus, were found, of which density of the genus Discocriconemella was highest with 330 individuals $/ 250 \mathrm{~g}$ soil $(87.3 \%$ of total). Roots of Bixa orellana also showed lesions similar as for Hymenocallis littoralis that might be caused by nematodes.

Excoecaria cochinchinensis was the medicinal plant parasitized by the highest number of plant-parasitic nematodes with five genera, namely Xiphinema, Discocriconemella, Meloidogyne, Helicotylenchus, and Hemicriconemoides. However, densities of these nematodes were relatively low, of which density of the genus Meloidogyne was highest with 30 individuals $/ 250 \mathrm{~g}$ soil (46.9\% of total). Roots of Excoecaria cochinchinensis also showed small galls, caused by genus Meloidogyne.

When it comes to frequency of nematodes on medicinal plants, genus Helicotylenchus was found on all medicinal plants except Hymenocallis littoralis (5/6 plants or 83.3\%), and four genera, including Paratylenchus, Criconemella, Tylenchulus, and Scutellonema, were found on only one medicinal plant $(16.7 \%)$.

\section{DISCUSSION}

Ten species belonging to nine genera, five families, and two orders of plant-parasitic nematodes were found in the rhizosphere of six medicinal plants in Me Linh Station for Biodiversity, and among them, eight species are new records on medicinal plants in Vietnam (Ngo, 2000; Nguyen \& Nguyen, 2000; Nguyen et al., 2015). Although plantparasitic nematodes have been reported from many medicinal plants, this study provided nematode component associated with six new hosts in Vietnam (five hosts are new to the world) (Ngo, 2000; Nguyen \& Nguyen, 2000; Khanzada et al., 2007; Nguyen et al., 2015;
Abtahi \& Bakooie, 2017; Eapen \& Pandey, 2018).

Studies on medicinal plants previously reported that the root-knot nematode $(M$. incognita and $M$. javanica), the lesion nematode (Pratylenchus thornei), and the stunt nematode (Tylenchorhynchus vulgaris) were reported to be the most economically important nematodes on medicinal plants (Eapen \& Pandey, 2018). However, based on the density and frequency of nematodes in this study, Discocriconemella limitanea and Helicotylenchus spp. can be considered as potential pathogens to medicinal plants, because they were found as nematodes with the highest density and frequency. Therefore, based on this study, we recommend further studies on the occurrence and possible impact of Discocriconemella limitanea, Helicotylenchus spp., and Meloidogyne incognita on medicinal plants in Me Linh Station for Biodiversity, as well as other places, for the sustainable development of medicinal plants.

This study investigated plant-parasitic nematodes from suspected host plants with symptom such as stunting, yellow leaves, root knot, root lesion, and all studied medicinal plants in this study have been found to be associated with at least two plant-parasitic nematode genera. This result indicated that plant-parasitic nematodes are highly correlated to these symptoms, and therefore, plant-parasitic nematodes are probably the main reason for these damages.

Acknowledgements: This study was supported by the project code: IEBR.ThST.819 and BOF-DOS 01W02619.

\section{REFERENCES}

Abtahi F. \& Bakooie M., 2017. Medicinal Plant Diseases Caused by Nematodes. In: Ghorbanpour M. \& Varma A. (Eds.) Medicinal Plants and Environmental Challenges. Switzerland: Springer, $426 \mathrm{p}$.

De Ley P., 2006. A quick tour of nematode diversity and the backbone of nematode 
Nguyen Hии Tien et al.

phylogeny. WormBook: the online review of C. elegans biology, 25: 1-8.

Eapen S. J. \& Pandey R., 2018. Nematode Parasites of Spices and Medicinal Plants. In: Sikora R. A., Coyne D., Hallmann J. \& Timper P. (Eds.). Plant parasitic nematodes in subtropical and tropical agriculture. 3rd ed. UK: CABI, 877 p.

Hallem E. A., Dillman A. R., Hong A. V., Zhang Y., Yano J. M., Demarco S. F. \& Sternberg P. W., 2011. A sensory code for host seeking in parasitic nematodes. Current Biology 21: 377-383.

Hartman K. M. \& Sasser J. N., 1985. Identification of Meloidogyne species on the basis of differential hosts test and perineal pattern morphology. In: Barker K. R., Carter C. C. \& Sasser J. N. (Eds.) An advanced treatise on Meloidogyne. North Carolina State University Graphics, Raleigh, North Carolina, USA, 69-77 p.

Hassan M. A., Pham T. H., Shi H. \& Zheng J., 2013. Nematodes threats to global food security. Acta Agriculturae Scandinavica, Section B - Soil \& Plant Science 63: 420-425.

Hickman C. P., Roberts L. S. \& Larson A., 2003. Animal diversity (No. 591 H628a), New York, US: McGraw-Hill Higher Education, $447 \mathrm{p}$.

Khanzada S. A., Munir A., Jamal A., Ahmed Z. \& Bashir M., 2007. Nematode fauna associated with medicinal plants. Pakistan Journal of Nematology, 25: 53-58.

Ngo T. X., 2000. Study on biological characterisation and prevention ability of root-knot nematode (Meloidogyne incognita (Kofoid et White, 1919) Chitwood, 1949) on some crops in Hanoi and surrounding areas. Doctoral thesis. (in Vietnamese)

Nguyen H. T., Nguyen T. D., Le T. M. L., Trinh Q. P. \& Nguyen T. T., 2015. Preliminary study on plant parasitic nematodes on some important herbs in dong trieu (Quang Ninh Province). The $6^{\text {th }}$ national conference on ecology and biological resources: 928-933.

Nguyen H. T., Le T. M. L., Nguyen T. D., Liebanas G., Nguyen T. A. D. \& Trinh Q. P., 2019a. Description of Geocenamus vietnamensis $\mathrm{sp}$. n. (Nematoda: Merliniidae) from Vietnam. Journal of nematology, 51: 1-12.

Nguyen H. T., Trinh Q. P., Couvreur M., Singh P. R., Decraemer W. \& Bert W., 2019b. Molecular and morphological characterisation of a new root-lesion nematode, Pratylenchus horti n. sp. (Tylenchomorpha: Pratylenchidae), from Ghent University Botanical Garden. Nematology, 21: 739-752.

Nguyen N. C. \& Nguyen, V. T., 2000. Fauna of Vietnam, Plant-parasitic nematodes. Publish House for Science and Technology, $401 \mathrm{p}$.

Nguyen T. D., Le T. M. L., Nguyen H. T., Nguyen T. a. D., Liébanas G. \& Trinh Q. P., 2017. Morphological and molecular characteristics of Pratylenchus haiduongensis $\mathrm{sp}$. $\mathrm{n}$., a new species of root-lesion nematode associated with carrot in Vietnam. Journal of Nematology, 49: 276-285.

Perry R. \& Moens M., 2013. Plant nematology: CABI, $542 \mathrm{p}$.

Randig O., Bongiovanni M., Carneiro R. M. \& Castagnone-Sereno P., 2002. Genetic diversity of root-knot nematodes from Brazil and development of SCAR markers specific for the coffee-damaging species. Genome, 45: 862-870.

Whitehead A. G. \& Hemming J. R., 1965. A comparison of some quantitative methods of extracting small vermiform nematodes from soil. Annales of Applied Biology, 55: 25-38. 